\title{
LITERASI KEAGAMAAN DAN KARAKTER PESERTA DIDIK
}

Ide penyederhanaan kurikulum pendidikan dasar dan menengah yang fokus pada tiga hal yakni literasi, numerasi dan karakter pada dasarnya dalam kerangka peningkatan mutu pendidikan. Harapannya agar peserta didik kuat dalam kemampuan menganalisis dan menyelesaikan problem masa depan dengan berbasis pada data (literasi). Selain itu, peserta didik juga diharapkan memiliki karakter yang baik. Isi buku ini memang tidak secara langsung terkait dengan ide penyederhanaan kurikulum tersebut, tetapi artikel-artikel dalam buku ini yang berkaitan dengan literasi dan karakter bisa menjadi refleksi atas peningkatan mutu pendidikan khususnya. Buku dapat menjadi bahan untuk merespon inovasi pendidikan yang dicanangkan oleh Kementerian Pendidikan dan Kebudayaan.

Editor: Aji Sofanudin dan Ahmad Muntakhib
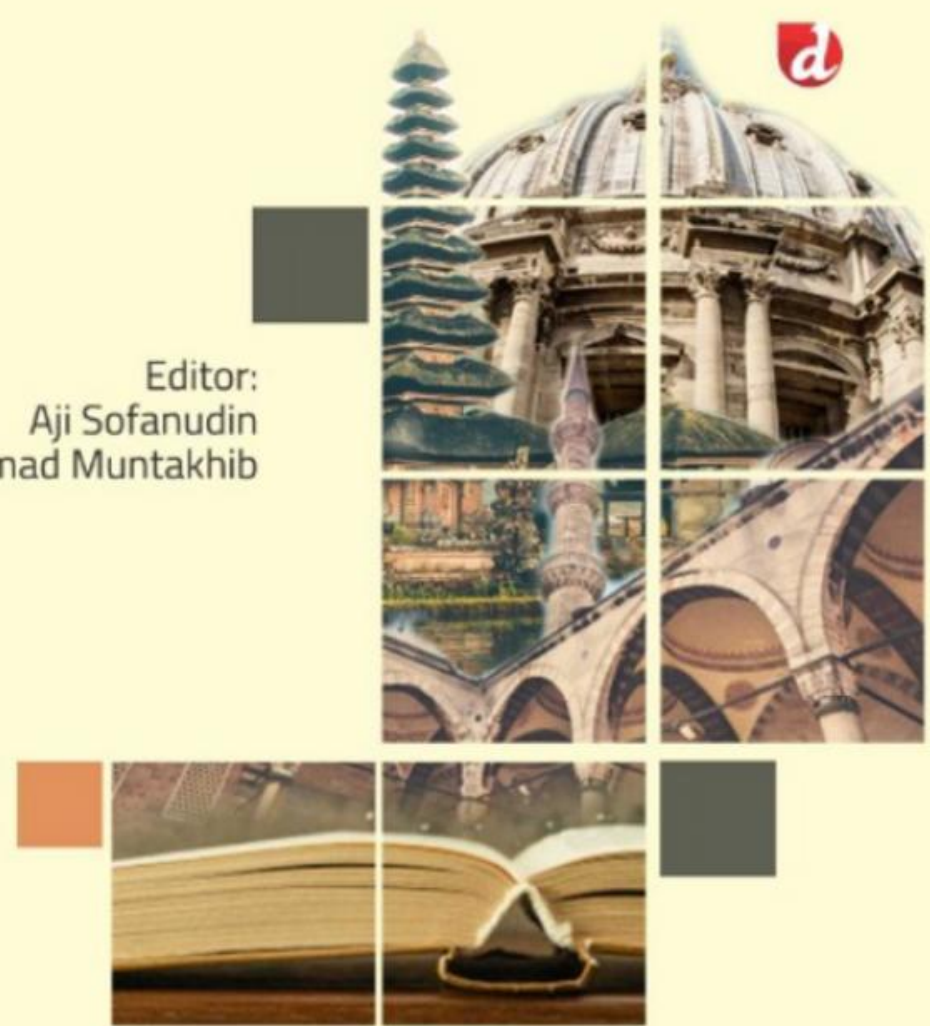

\section{LITERASI KEAGAMAAN DAN KARAKTER PESERTA DIDIK}

Aji Sofanudin, dkk

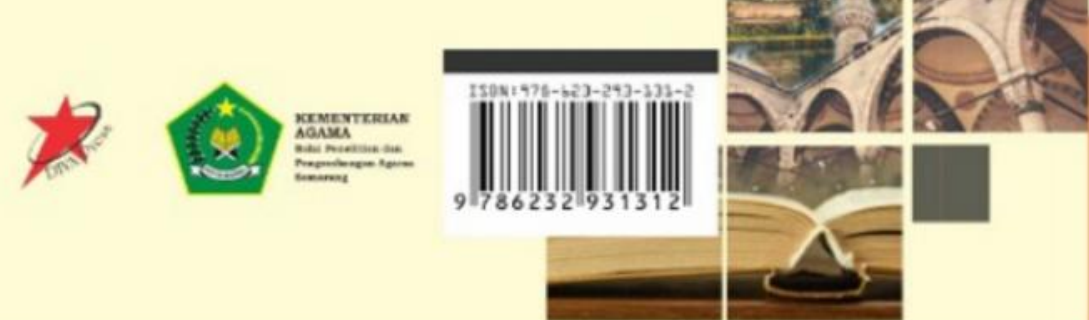




\section{Aji Sofanudin, dkk}

\section{LITERASI KEAGAMAAN DAN KARAKTER PESERTA DIDIK}




\section{LITERASI KEAGAMAAN DAN KARAKTER PESERTA DIDIK}

Penulis: Aji Sofanudin, dkk

Editor: Aji Sofanudin dan Ahmad Muntakhib

Tata Sampul: Quella

Tata Isi: Mohammad Hasib

Pracetak: Antini, Dwi, Wardi

Cetakan Pertama, November 2020

Penerbit

DIVA Press

(Anggota IKAPI)

Sampangan Gg. Perkutut No.325-B

Jl. Wonosari, Baturetno

Banguntapan Yogyakarta

Telp: (0274) 4353776, 081804374879

Fax: (0274) 4353776

E-mail:redaksi_divapress@yahoo.com sekred2.divapress@gmail.com

Blog: www.blogdivapress.com

Website: www.divapress-online.com

Bekerjasama dengan Balai Penelitian dan Pengembangan Agama Semarang

Jl. Untung Suropati Kav. 70 Bambankerep, Ngaliyan, Semarang

(KP) 50185, Telp. (024) 7601327, Fax. (024) 7611386

Email: bla_semarang@kemenag.go.id

Perpustakaan Nasional: Katalog Dalam Terbitan (KDT)

Sofanudin, Aji, dkk

Literasi Keagamaan dan Karakter Peserta Didik/Aji Sofanudin, dkk; editor, Aji Sofanudin dan Ahmad Muntakhib-cet. 1-Yogyakarta: DIVA Press, 2020

viii +312 hlmn; 15,5 × $24 \mathrm{~cm}$

ISBN 978-623-293-131-2

I. Judul

II. Aji Sofanudin dan Ahmad Muntakhib 


\section{PENGANTAR EDITOR}

Tema "Literasi dan Survei Karakter" merupakan dua isu penting dalam dunia Pendidikan. Penyederhanaan sistem evaluasi pendidikan yang tidak lagi berbasis "mata pelajaran" menempatkan literasi dan karakter menjadi dua hal yang urgen. Meskipun buku ini tidak terkait langsung dengan isu penyederhanaan kurikulum, namun bisa menjadi sumbangan berharga bagi penyusunan kebijakan, khususnya oleh Kementerian Agama. Kumpulan tulisan dengan tema literasi dan survei karakter bisa menjadi bahan masukan terkait kebijakan penyederhanaan kurikulum yang digagas Kementerian Pendidikan dan Kebudayaan. Ujian Nasional yang sedianya dihapus tahun 2021 ternyata sudah ditiadakan mulai tahun 2020. Melalui Surat Edaran Menteri Pendidikan dan Kebudayaan, Nomor 4 Tahun 2020 tentang Pelaksanaan Kebijakan Pendidikan dalam Masa Darurat Penyebaran Corona Virus Disease (Covid-19), Ujian Nasional tahun 2020 dibatalkan. Numerasi, Literasi, dan Survei Karakter digadang-gadang akan mengganti sistem evaluasi yang berbasis mata pelajaran. Ketiganya akan menjadi standar dalam sistem evaluasi pendidikan dasar dan menengah.

Bunga rampai ini berisi dua tema terkait isu penyederhanaan kurikulum, yakni literasi dan survei karakter. Buku "Literasi Keagamaan dan Karakter Peserta Didik" merupakan naskah yang bersumber dari hasil penelitian Tim Peneliti Balai Penelitian dan Pengembangan Agama Semarang. Ada dua tema besar dalam buku ini yaitu terkait Literasi Keagamaan dan Survei Karakter Peserta Didik. Tema Literasi berasal dari Tim Peneliti bidang Lektur, Khasanah Keagamaan dan Manajemen Organisasi. Sementara tema survei karakter berasal dari Tim Peneliti bidang Pendidikan Agama dan Keagamaan Balai Penelitian dan Pengembangan Agama Semarang. 
Penyusunan bunga rampai ini melalui berbagai tahapan panjang, mulai dari pengumpulan naskah sampai dengan penerbitan. Secara formal dilakukan tiga kali rapat: pengumpulan, pembahasan dan finalisasi. Berbagai pihak banyak terlibat dalam mengawal penyusunan buku ini. Pambahasan naskah ini melibatkan para reviewer baik dari internal kantor (TPMPP) maupun eksternal. Oleh karena itu, dalam kesempatan ini tim editor mengucapkan terima kepada para reviewer internal: Joko Tri Haryanto, Wahab, Mulyani Mudis Taruna, Roch Aris Hidayat, dan Agus Iswanto. Selain itu, editor juga mengucapkan terima kasih kepada reviewer eksternal dari perguruan tinggi: Ahwan Fanani, Tolkhatul Khoir, Noor Miyono, dan Mibtadin serta berbagai pihak yang terlibat baik langsung maupun tidak langsung sehingga penerbitan ini bisa selesai.

Kami menyadari bahwa "tak ada gading yang tidak retak", tak ada satupun di dunia ini yang sempurna. Oleh karena itu, mohon masukan, kritik dan saran dari pembaca semua untuk kesempurnaan penerbitan buku di masa yang akan datang.

Selamat membaca.

Semarang, 30 Juli 2020 Aji Sofanudin

Ahmad Muntakhib 


\section{DAFTAR ISI}

Sambutan Kepala Balai Penelitian dan Pengembangan

Agama Semarang ................................................ iii

Pengantar Editor......................................................

Prolog

Literasi, Numerasi, dan Survei Karakter (Aji Sofanudin)..... 3

\section{Bagian I Literasi Keagamaan}

Praktik Literasi Keagamaan Pada Siswa Madrasah

Aliyah Berbasis Pesantren (Mustolehudin) .................... 17

Literatur Keagamaan Pada SMA di Bawah Yayasan

Keagamaan Katolik (Umi Masfiah)................................. 49

Praktik Literasi Keagamaan Mahasiswa Uin Sunan

Ampel Surabaya (Moch Lukluil Maknun) ........................ 83

\section{Bagian II Karakter Peserta Didik}

Indeks Karakter Peserta Didik di Provinsi Bali

(Aji Sofanudin dan Wahab)

Integrasi Pendidikan Karakter Peserta Didik

di Kabupaten Pasuruan (Ahmad Muntakhib)

143 
Indeks Karakter Peserta Didik di Kabupaten

Pamekasan (Nugroho Eko Atmanto)

Survei Karakter Peserta Didik di Kabupaten Tuban

dan Jombang (Mulyani Mudis Taruna dan Abdul Rohman) 191

Potret Karakter Peserta Didik di Kabupaten Kediri

dan Jombang (A.M. Wibowo)

223

Survei Karakter Peserta Didik di Kabupaten Kediri dan Malang (Wahab)

Epilog

Tantangan Pendidikan Karakter dan Literasi

(Ahwan Fanani)

271

Bibliografi

283

Biodata Penulis. 301

Indeks 


\section{LITERASI KEAGAMAAN}

\section{DAN KARAKTER PESERTA DIDIK}

Editor:

Aji Sofanudin dan Ahmad Muntakhib 


\title{
INDEKS KARAKTER PESERTA DIDIK DI PROVINSI BALI
}

\author{
Aji Sofanudin dan Wahab
}

\section{Pendahuluan}

Karakter merupakan bagian penting dalam proses pendidikan di Indonesia. Undang-undang Nomor 20 Tahun 2003 tentang Sisdiknas mengamanatkan dalam Pasal 3 bahwa, "Pendidikan nasional berfungsi mengembangkan kemampuan dan membentuk watak serta peradaban bangsa yang bermartabat dalam rangka mencerdaskan kehidupan bangsa". Di sisi lain, tujuan pendidikan adalah "untuk berkembangnya potensi peserta didik agar menjadi manusia yang beriman dan bertakwa kepada Tuhan Yang Maha Esa, berakhlak mulia, sehat, berilmu, cakap, kreatif, mandiri, dan menjadi warga negara yang bertanggung jawab".

Pendidikan karakter secara implisit juga ada dalam Undang undang Dasar (UUD) 1945. Dalam pasal 31 ayat 3 menyebutkan, pemerintah mengusahakan dan menyelenggarakan satu sistem pendidikan nasional yang meningkatkan keimanan dan ketakwaan serta akhlak mulia dalam rangka mencerdaskan kehidupan bangsa yang diatur dengan undang-undang.

Untuk mengembangkan pendidikan karakter secara lebih sistematis, pemerintah mengeluarkan Peraturan Presiden Nomor 87 Tahun 2017 tentang Penguatan Pendidikan Karakter (PPK). Dalam implementasinya Kementerian dan Kebudayaan, menetapkan tiga pendekatan PPK yaitu pendidikan karakter berbasis kelas, budaya sekolah dan masyarakat (keluarga) atau komunitas (Muhadjir Effendy, 2017: 17). Pendidikan karakter berbasis kelas sudah banyak dilakukan dalam bentuk modifikasi Rencana Pelak- 
sanaan Pembelajaran (RPP), namun pendidikan karakter berbasis budaya sekolah/ madrasah belum banyak diungkap.

Kementerian Pendidikan mengenalkan empat konsep strategi Pendidikan karakter yaitu (1) melalui kegiatan belajar mengajar di kelas, (2) pembiasaan dalam kehidupan sehari-hari di satuan pendidikan, (3) kegiatan ekstrakurikuler dan (4) kegiatan keseharian di rumah dan masyarakat (Komalasari, 2017: 26). Persoalan karakter bukanlah sesuatu yang baru. Bung Karno sering menyebutnya sebagai national and character building. Dalam Bahasa agama sering disebut dengan akhlak.

Pendidikan memiliki dua tujuan utama, yaitu membantu manusia menjadi cerdas (smart) dan membantu manusia menjadi manusia yang baik (good). Pendidikan perlu menyeimbangkan antara akal dan qalb. Sayangnya, praktik pendidikan yang ada tidak seimbang dan lebih dominan mengisi akal dan menyampingkan qalb. Pendidikan lebih cenderung fokus kepada knowledge and skill, pendidikan kognitif dan berorientasi akademik. Oleh Karena itulah dibutuhkan pendidikan karakter.

Karakter melekat pada setiap individu, yang tercermin pada pola perilaku dalam kehidupan sehari-hari. Karakter seseorang dipengaruhi oleh faktor lingkungan (nurture) dan faktor bawaan (nature). Pendidikan karakter merupakan suatu keniscayaan dalam upaya menghadapi berbagai tantangan pergeseran karakter yang dihadapi saat ini. Pendidikan karakter ini bertujuan mengembangkan kemampuan seseorang untuk memberikan keputusan baik-buruk, memelihara apa yang baik dan mewujudkan kebaikan itu dalam kehidupan sehari-hari dengan sepenuh hati. Karena pendidikan karakter merupakan suatu habit, maka pembentukan karakter seseorang itu memerlukan communities of character. Peran sekolah sebagai communities of character dalam pendidikan karakter sangat penting. Sekolah mengembangkan proses pendidikan karakter melalui proses pembelajaran, habituasi, kegiatan ekstrakurikuler, dan bekerja sama dengan keluarga dan masyarakat dalam pengembangannya (Komalasari dan Didin, 2017: 1).

Riset terkait akhlak atau karakter sudah banyak dilakukan. Dengan menggunakan pendekatan kualitatif model CIPP (Context, Input, Process, Product) riset Sofanudin (2015) menghasilkan empat temuan, yaitu: (1) secara konteks, strategi penanaman 
nilai-nilai karakter bangsa melalui mata pelajaran agama dilakukan melalui kebijakan kepala sekolah, sistem sekolah, kualitas sarana dan prasarana, serta iklim dan budaya yang mendukung internalisasi pendidikan karakter di sekolah; (2) secara input, internalisasi nilai-nilai karakter bangsa telah dilakukan melalui kualifikasi dan kompetensi guru, input sarana dan prasarana, serta kualifikasi peserta didik; (3) proses internalisasi nilai-nilai karakter bangsa dilakukan melalui kurikulum PAI berupa kegiatan intrakurikuler, kegiatan ekstrakurikuler, dan pembiasaan sekolah; (4) produk yang dihasilkan dari internalisasi nilai-nilai karakter bangsa melalui PAI adalah peserta didik yang kompeten dan memiliki karakter yang baik.

Lickona (1992:51) menekankan pentingnya tiga komponen karakter yang baik, yaitu di mana "character so conceived has three interrelated parts: moral knowing, moral feeling and moral behaviour. Good character consists of knowing the good, desiring the good and doing the good habits of the mind, habits of the heart and habits of action". Karakter yang baik terdiri atas mengetahui kebaikan (knowing the good), mencintai atau menginginkan kebaikan (loving or desiring the good) dan melakukan kebaikan (acting the good). Oleh Karena itu, cara membentuk karakter yang efektif adalah dengan melibatkan ketiga aspek tersebut.

Pendidikan karakter mengandung tiga elemen penting yaitu mengetahui hal baik, mencintai kebaikan, dan melakukan kebaikan. Pendidikan bukan sekedar mengajarkan hal yang baik dan buruk, lebih dari itu dibutuhkan pembiasaan sehingga karakter tersebut benar-benar melekat pada anak.

Dalam Permendikbud Nomor 20 Tahun 2018 tentang penguatan pendidikan karakter (PPK), disebutkan bahwa PPK adalah gerakan pendidikan di bawah tanggung jawab satuan pendidikan untuk memperkuat karakter peserta didik melalui harmonisasi olah hati, olah rasa, olah pikir, dan olah raga dengan pelibatan dan kerja sama antara satuan pendidikan, keluarga, dan masyarakat sebagai bagian dari Gerakan Nasional Revolusi Mental (GNRM). Karakter peserta didik menyangkut lima dimensi: religiusitas, nasionalisme, kemandirian, gotong royong, dan integritas.

Permasalahan pokok dalam penelitian ini adalah bagaimana karakter peserta didik SMA dan MA dilihat dari lima dimensi 
karakter sebagaimana kebijakan pemerintah dalam Penguatan Pendidikan Karakter di sekolah/madrasah. Secara operasional penelitian ini bertujuan untuk mengetahui indeks karakter peserta didik pada SMA dan MA di Propinsi Bali. Penelitian ini merupakan bagian dari survei nasional karakter peserta didik SMA dan MA tahun 2019 yang diselenggarakan oleh Puslitbang Pendidikan Agama dan Keagamaan, Badan Litbang dan Diklat Kementeraian Agama RI.

\section{Kerangka Pikir}

Secara etimologi, karakter adalah istilah netral. Sejatinya, dengan atau tanpa pendidikan karakter setiap peserta didik pastilah memiliki karakter; baik atau pun buruk. Karakter adalah tabiat, watak, akhlak yang dimiliki setiap orang. Dalam aplikasinya, istilah karakter selalu bermakna sesuatu yang baik atau positif. Hal ini berbeda dengan istilah "radikal", secara etimologi bermakna netral, tetapi dalam aplikasinya berkonotasi peyoratif atau jelek. Radikalisme bermakna garis keras dan cenderung ekstrim, sementara karakter berarti akhlaqul karimah, moral, watak dan perilaku terpuji.

Karakter memiliki makna watak, tabiat dan kepribadian. Menurut Nata (2018:275-300), kepribadian dalam Islam terdiri atas dua macam yaitu pertama kepribadian yang baik, dan kedua adalah kepribadian yang buruk. Kepribadian yang baik menurut Al-Qur'an adalah: al-mu'minun, al-muhlisin, al-muttaqun, al-muhsinun, shadiqun, al-muflihun, ibad al-rahman, mukhlisun, al-rasyidun, al-mutawakkilun, almuhtadun, ulama, al-rasikhuna fi al-ilm, ulu al-Bab, ulu al-Nuha, ulu alllm, ahl-dzikr. Kepribadian yang buruk adalah: kafirun, munafiqun, ghafilun, al-fasiqun, aldzalimun, al-jahilun, dan al-khasirun.

Kepribadian al-mu'minun, adalah orang-orang yang beriman (QS Al-Anfal, [8]:2). Kepribadian al-muslimun, adalah orang-orang Islam. di dalam Al-Qur'an, kata al-muslim atau al-muslimun diulang sebanyak 46 kali. Kata al-muslimun antara lain dijelaskan dalam QS Ali Imron [3]: 67. Kepribadian al-muhlisin, orang-orang yang ikhlas ada dalam Al-Baqarah [2]:130. Kepribadian, al-muttaqun, 
orang-orang yang bertakwa adalah dalam QS Al-Baqarah [2]: 2-5; QS AlBaqarah [2]: 177; QS Ali Imran [3]: 133-135.

Kata muhsin atau al-muhsinun, terulang sebanyak 40 kali, tidak termasuk kata yang serumpun dengannya seperti hasuna, ahsana, hasanah al-husna, atau ihsan. Kata muhsinun terkadang dihubungkan dengan orang-orang yang menyerahkan dirinya kepada Allah sehingga berhak mendapatkan pahala dari Allah (QS Al-Baqarah [2]: 112; sebagai orang yang paling baik agamanya (QS An-Nisa [4]: 125); orang yang akan disertai oleh Allah SWT (QS An-Nahl [16]: 128; orang yang menahan amarahnya dan suka memaafkan manusia (QS Ali Imron [3]: 134); orang yang suka memaafkan dan berlapang dada (QS Al-Maidah [5]: 13); orang yang dekat dengan rahmat Allah (QS Al-A'raf [7]: 56); orang yang senantiasa bersujud kepada Allah (QS Al-A'raf [7]: 161; orang yang pahala kebaikannya tidak akan dicampakan oleh Allah SWT (QS At-Taubah [9]: 120); orang yang suka bersabar (QS Huud [11]: 115); orang yang senantiasa berjuang meninggikan kalimat Allah dan berjalan di jalan Allah (QS AlAnkabut [39]: 69); orang yang mendapat hidayah dan petunjuk dari Tuhan (QS Luqman [31]: 3); sebagai sifat yang baik terhadap Nabi Nuh, Nabi Ibrahim, Nabi Musa, dan Nabi Harun (QS Al-Shaffat [37]: 80, 105,110 dan 121.

Kata shadiqun dalam Al-Qur'an diulang sebanyak 58 kali. Kata al-shadiqun ada yang dihubungkan dengan orang yang selalu menyampaikan dengan benar (QS Al-Hijr [15]: 64), orang yang suka memberikan pertolongan (karena) Allah dan Rasul-Nya (AlHasyr [59]:8), digunakan sebagai kriteria yang baik bersama-sama orang yang bertakwa (QS At-Taubah [9]: 119), orang yang akan diberikan pahala oleh Allah yang disebabkan karena perbuatan baiknya (QS Al-Ahzab [33]: 24); sifat yang disebut bersamaan dengan orang-orang yang dapat mentaati aturan-aturan Allah SWT (QS Al-Ahzab [33]: 35).

Di dalam Al-Qur'an kata al-muflihun diulang sebanyak 15 kali. Kata al-muflihun dengan didahului oleh kata tidak akan mendapatkannya yaitu orang yang suka memperjualbelikan ayat-ayat Allah (QS An-Nahl [16]:116); orang yang mendapatkan hidayah dari Allah SWT (Al-Baqarah [2]:5) dan Luqman [31]:5); orang yang suka menyuruh kepada kebaikan dan melarang kemunkaran (QS Ali Imran [3]: 104); orang yang timbangan amal kebajikannya lebih besar daripada amal keburukannya (QS Al- 
A'raf [7]: 8 dan Al-Mu'minun [23]: 102); orang yang mendapatkan kebaikan (QS Al-Taubah [9]:88); orang yang mendengarkan seruan Allah dan mentaatinya (QS Al-Nuur [24]:51); orang yang senantiasa mengharapkan keridlaan Allah SWT (QS Al-Ruum [30]: 38); orang yang mencari tentara Allah (hizbullah) (QS Al-Mujadalah [58]: 22); orang yang dapat mengendalikan perasaan kikirnya (QS Al-Hasyr [59]: 9 dan Al-Taghabun [64]: 16) dan digunakan sebagai sebuah harapan kepada orang-orang yang berbuat baik agar mendapatkan kebahagiaan (QS Al-Qashash [28]: 64).

Kepribadian ibad al-rahman, secara harfiah berarti hambahamba Allah atau orang-orang yang mengabdikan dirinya hanya untuk Allah. Ciri-ciri ibad al-rahman ada dalam (QS Al-Furqon [25]: 62-75). Kata al-mukhlisun dalam Al-Qur'an diulang sebanyak 20 kali. Kata mukhlisun dihubungkan dengan perintah beribadah kepada Allah yang didahului dengan informasi tentang kekuasaan Allah yang menurunkan Al-Qur'an (QS Al-Zumar [39]: 2); berkaitan denganamal kebajikan yang dikerjakan (QS Al-Baqarah [2]: 139); terkait dengan perintah berdoa semata-mata karena Allah SWT (QS Ghafur [40]: 14); terkait dengan pernyataan mengesakan Allah SWT (QS Al Ghafir [40]: 65); perintah menyembah Allah SWT (QS Al-Bayyinah [97]: 5); sebagai sifat yang positif bagi Nabi Isa (QS Maryam [19]: 51).

Kata al-rasyidun di dalam Al-Qur'an diulang sebanyak 4 kali. Kata al-rasyidun berarti orang-orang yang mengikuti jalan yang lurus (QS Al-Hujurat [49]: 7), orang yang berakal (QS Hud [11]: 78 dan 87). Kata al-mutawakkilun disebut 4 kali di dalam Al-Qur'an. Kata almutawakkilun, orang yang bertawakkal, disebut dalam QS Yusuf [12]:67, QS Ibrahim [14]: 11, QS Ali Imran [3]: 159. Kata almuhtadun, diulang sebanyak 8 kali dalam Al-Qur'an. Kata almuhtadun, orang yang mendapat petunjuk, terdapat dalam QS AlBaqarah [2]: 153-157, QS Al-An'am [6]: 117, QS Al-Taubat [9]: 18.

Seorang ulama adalah orang yang bertakwa atau takut melanggar larangan Allah, dan takut meninggalkan perintah-Nya, serta merasa demikian kecil dan rendah diri di hadapan Allah serta tidak berani melawan-Nya (QS Fathir [35]: 27-28). Kata alrasikhuna fi alilm mengandung arti orang yang mendalam ilmunya dan lurus dalam menafsirkan ayat-ayat Allah, baik ayat-ayat yang mutasyabihat (ayat yang mengandung makna beragam) maupun ayat yang muhkamat (ayat yang mengandung makna yang pasti). 
Ia meyakini semua ayat itu sama-sama dari Allah SWT dan di dalamnya mengandung hikmah, pelajaran dan didikan yang mendalam (QS Ali Imran [3]: 7).

Ulu al-Bab adalah seorang yang berakal yang senantiasa menyeimbangkan penggunaan kekuatan zikir dan pikir untuk memahami segala ciptaan Allah yang berada di langit dan di bumi, hingga menemukan bukti tanda kekuasaan Tuhanmu (QS Ali Imran [3]: 190-194). Ulu al-Nuha, orang yang berakal, ditandai oleh karakter yang senantiasa memikirkan ciptaan Allah yang terdapat pada makanan yang dimakan, hewan gembalaan, serta berbagai peristiwa dalam sejarah. Di dalam peristiwa tersebut terdapat pelajaran yang amat berharga bagi manusia (QS Thaha [20]: 54-55 dan 128.

Ulu al-Ilm,orang yang berilmu adalah orang yang mengetahui bahwa sesungguhnya tidak ada Tuhan selain Allah dan juga senantiasa menegakkan keadilan (QS Ali Imran [3]: 18). Ahl-dzikr, orang yang mempunyai pengetahuan, yaitu orang yang mempunyai pengetahuan tentang nabi dan kitab-kitab, dan karenanya ia dipercaya sebagai master, guru, referensi, narasumber dan expert. Yaitu orang yang dapat memberikan jawaban atau pemecahan masalah berdasarkan bukti-bukti ilmiah dan analisis yang bersifat saintifik (QS AnNahl [16]: 43).

Kepribadian yang buruk dalam Al-Qur'an adalah: kafirun (QS Al-Baqarah [2]: 6-7); munafiqun (QS Al-Baqarah [2]: 8-16); ghafilun, orang yang lalai (QS Al-A'raf [7]: 179); al-fasiqun, (QS Al-Maidah [5]: 47; Al-Taubah [9]: 67, dan Ash-Shaff [61]: 5); al-dzalimun (QS Al-Maidah [5]: 45), al-jahilun (QS Al-Baqarah [2]: 273 dan 67), dan al-khasirun (QS Al-Baqarah [2]: 27 dan Al-Ankabut [29]: 52).

Istilah karakter berasal dari bahasa Yunani charassein, yang berarti to engrave atau mengukir. Membentuk karakter diibaratkan seperti mengukir di atas batu permata atau permukaan besi yang keras. Dari sanalah kemudian berkembang pengertian karakter yang diartikan sebagai tanda khusus atau pola perilaku. Ada dua pengertian tentang karakter. Pertama, ia menunjukkan bagaimana seseorang bertingkah laku. Apabila seseorang berperilaku tidak jujur, kejam, atau rakus, tentulah orang tersebut memanifestasikan perilaku buruk. Sebaiknya, apabila seseorang berperilaku jujur, suka menolong, tentulah orang tersebut memanifestasikan 
karakter mulia. Kedua, istilah karakter erat kaitannya dengan 'personality'. Seseorang baru bisa disebut 'orang yang berkarakter' (a person of character) apabila tingkah lakunya sesuai kaidah moral (Komalasari dan Saripudin, 2107:2).

Thomas Lickona (1992: 52) memberikan definisi yang sangat lengkap mengenai karakter. Menurut Lickona karakter adalah " $a$ reliable inner disposition to respond to situations in a morally good way". Lickona juga menambahkan bahwa "character so conceived has three interrelated parts: moral knowing, moral feeling, and moral behaviour" (Lickona, 1992: 51). Karakter mulia (good character) dalam pandangan Lickona, meliputi pengetahuan tentang kebaikan (moral knowing), lamu menimbulkan komitmen (niat) terhadap kebaikan (moral feeling), dan akhirnya benar-benar melakukan kebaikan (moral behaviour). Dengan kata lain, karakter mengacu kepada serangkaian pengetahuan (cognitive), sikap (attitudes), dan motivasi (motivations), serta perilaku (behaviors), dan keterampilan (skills).

Badan Penelitian dan Pengembangan Kementerian Pendidikan telah merumuskan 18 nilai karakter yaitu:

a. Religius: Sikap dan perilaku yang patuh dalam melaksanakan ajaran agama yang dianutnya, toleran terhadap pelaksanaan ibadah agama lain, dan hidup rukun dengan pemeluk agama lain.

b. Jujur: Perilaku yang didasarkan pada upaya menjadikan dirinya sebagai orang yang selalu dapat dipercaya dalam perkataan, tindakan, dan pekerjaan.

c. Toleransi: Sikap dan tindakan yang menghargai perbedaan agama, suku, etnis, pendapat, sikap, dan tindakan orang lain yang berbeda dari dirinya.

d. Disiplin: Tindakan yang menunjukkan perilaku tertib dan patuh pada berbagai ketentuan dan peraturan.

e. Kerja Keras: Tindakan yang menunjukkan perilaku tertib dan patuh pada berbagai ketentuan dan peraturan.

f. Kreatif: Berpikir dan melakukan sesuatu untuk menghasilkan cara atau hasil baru dari sesuatu yang telah dimiliki.

g. Mandiri: Sikap dan perilaku yang tidak mudah tergantung pada orang lain dalam menyelesaikan tugas-tugas. 
h. Demokratis: Cara berfikir, bersikap, dan bertindak yang menilai sama hak dan kewajiban dirinya dan orang lain.

i. Rasa Ingin Tahu: Sikap dan tindakan yang selalu berupaya untuk mengetahui lebih mendalam dan meluas dari sesuatu yang dipelajarinya, dilihat, dan didengar.

j. Semangat Kebangsaan: Cara berpikir, bertindak, dan berwawasan yang menempatkan kepentingan bangsa dan negara di atas kepentingan diri dan kelompoknya.

k. Cinta Tanah Air: Cara berpikir, bertindak, dan berwawasan yang menempatkan kepentingan bangsa dan negara di atas kepentingan diri dan kelompoknya.

1. Menghargai Prestasi: Sikap dan tindakan yang mendorong dirinya untuk menghasilkan sesuatu yang berguna bagi masyarakat, dan mengakui, serta menghormati keberhasilan orang lain.

m. Bersahabat/Komunikatif: Sikap dan tindakan yang mendorong dirinya untuk menghasilkan sesuatu yang berguna bagi masyarakat, dan mengakui, serta menghormati keberhasilan orang lain.

n. Cinta Damai: Sikap dan tindakan yang mendorong dirinya untuk menghasilkan sesuatu yang berguna bagi masyarakat, dan mengakui, serta menghormati keberhasilan orang lain.

o. Gemar Membaca: Kebiasaan menyediakan waktu untuk membaca berbagai bacaan yang memberikan kebajikan bagi dirinya.

p. Peduli Lingkungan: Sikap dan tindakan yang selalu berupaya mencegah kerusakan pada lingkungan alam di sekitarnya, dan mengembangkan upaya-upaya untuk memperbaiki kerusakan alam yang sudah terjadi.

q. Peduli Sosial: Sikap dan tindakan yang selalu ingin memberi bantuan pada orang lain dan masyarakat yang membutuhkan.

r. Tanggung Jawab: Sikap dan perilaku seseorang untuk melaksanakan tugas dan kewajibannya, yang seharusnya dia lakukan, terhadap diri sendiri, masyarakat, lingkungan (alam, sosial dan budaya), negara dan Tuhan Yang Maha Esa 
Dari 18 nilai karakter tersebut dapat diperas menjadi lima nilai karakter yaitu: religiusitas, nasionalisme, kemandirian, gotong royong, dan integritas.

\section{Metode Penelitian}

Penelitian ini dirancang dengan menggunakatan metode kuantitatif survei. Secara nasional jurnal sampel sebanyak 11.530 siswa kelas XI SMA dan MA yang tersebar di seluruh Indonesia. Sampel di Provinsi Bali sebanyak 170 siswa kelas XI SMA dan MA yang tersebar di Kota Denpasar, Kabupaten Badung, Kabupaten Karangasem, dan Kabupaten Buleleng. Margin of Error (MoE) sebesar $3 \%$.

Pengumpulan data dilakukan oleh 2 peneliti dan 4 surveyor. Pengumpulan data dilakukan 21 April s.d 27 April 2019. Dari 17 satuan pendidikan (1 MA dan 16 SMA), terdapat 1 SMA yang diganti karena kelas XI sedang melakukan PPL dalam waktu 1 bulan sehingga tidak bisa dilakukan pengambilan data. SMA tersebut diganti dengan sekolah lain yang sejenis, sama-sama SMA Pariwisata.

Penarikan sampel kab/kota dilakukan oleh Puslitbang Pendidikan Agama dan Keagamaan dengan multi stage sampling, sebanyak $169 \mathrm{kab} /$ kota secara probability sampling. Menarik sampel SMA dan MA secara independen di setiap strata sekolah secara sistematik dengan penerapan implicit stratifikasi berdasarkan status negeri dan swasta. Di setiap sekolah/madrasah terpilih dilakukan penarikan sampel siswa sebanyak 10 orang secara sistematik, setelah diurutkan berdasarkan nama-nama siswa di kelas XI.

Secara praktis ketika peneliti dan surveyor datang ke sekolah/ madrasah terpilih dilakukan beberapa tahapan sebagai berikut (1) Di setiap sekolah/madrasah terpilih diurutkan terlebih dahulu namanama siswa per kelas mulai misal kelas 11-a sd 11-f, beri nomor urut dari 1 sd N, misalkan $\mathrm{N}=200$; (2) Tahap 2, tentukan interval sampel, yaitu $\mathrm{I}=\mathrm{N} / 10=200 / 10=20$; (3) Tahap 3, tentukan angka random yang kurang dari 20, misal secara acak dapat 5, maka 5 merupakan Random pertama (R1), dan (4) Tahap 4, tentukan Random selanjutnya dg rumus $\mathrm{Rn}=\mathrm{R} 1+(\mathrm{n}-1)$.I, yaitu 
$\mathrm{R} 2=5+(1) \cdot 20=25, \mathrm{R} 3=5+(2) \cdot 20=45, \mathrm{dst} \ldots \ldots . \mathrm{sd}$ R10; dan (5) Tahap 5, angka random yang bersesuaian dengan nomor urut siswa menjadi nomor urut siswa terpilih untuk diwawancarai. Dari contoh siswa dg nomor urut 5, 25, 45, dst.... terpilih.

Variable penelitian karakter meliputi 5 dimensi yaitu: (1) religiusitas; (2) nasionalisme; (3) kemandirian; (4) gotong royong; dan (5) integritas. Adapun definisi konseptual dan definisi operasional masing-masing variabel adalah sebagai berikut.

Pertama, karakter religiusitas. Definisi Konseptual Religiusitas adalah keyakinan dan praktek yang bersifat keagamaan. Definisi operasional adalah keyakinan keagamaan yang menjadi dasar keimanan seorang penganut agama yang bersifat eksklusif dan praktek keagamaan yang bersifat ekstrinsik atau sosial dan intrinsik atau personal dan menjadi pembentuk identitas yang menonjol pada seseorang atau kelompok.

Kedua, karakter nasionalisme. Definisi konseptual cinta tanah air yang menjadi dasar identitas dan kepribadian personal dan kebangsaan. Definisi operasional cinta tanah yang menjadi dasar identis dan kepribadian personal dan kebangsaan yang diwujudkan melalui dimensi kecintaan terhadap tanah air, rasa bangga terhadap tanah air, kelekatan psikologis dengan tanah air, komitmen terhadap tanah air dan keinginan memberikan pelayanan atau pengabdian kepada tanah air dan bangsa.

Ketiga, karakter kemandirian. Definisi konseptual adalah bebas dari kendali orang lain atau memiliki kebebasan dan pengaruh terhadap diri sendiri. Definisi operasional kemandirian adalah kebebasan mengendalikan diri dalam urusan pribadi, baik di rumah atau di sekolah atau pergaulan sosial di luar rumah dan sekolah.

Keempat, karakter gotong royong. Definisi konseptual gotong royong adalah ilai dan perilaku bekerjasama di dalam kehidupan sosial. Definisi operasional gotong royong adalah nilai dan perilaku kerjasama yang terwujud dalam berbagai bentuk yaitu kepedulian lingkungan, raihan tujuan bersama (shared goal setting), interdependensi, dan pemecahan masalah bersama.

Kelima, karakter integritas. Definisi konseptual integritas adalah komitmen dan konsistensi seseorang terhadap nilai fundamental. Definisi operasional integritas adalah komitmen dan konsistensi terhadap lima nilai fundamental, yaitu kejujuran, 
keadilan, kepercayaan, tanggungjawab dan penghormatan sebagai kode moral dan kebijakan etis yang harus dimiliki seseorang dalam berbagai bidang kehidupan termasuk kehidupan siswa baik di sekolah maupun di luar sekolah.

Teknik analisis data yang digunakan dalam penelitian ini adalah frekuensi dan persentase, digunakan untuk menganalisis data demografis responden, diantaranya usia, jenis kelamin, dan jurusan.

\section{Temuan dan Pembahasan}

Pembangunan daya saing bangsa memerlukan nilai-nilai karakter. Permasalahan bangsa bukan semata terletak minimnya pengetahuan, keterampilan dan kompetensi tetapi hilangnya karakter para pemimpin bangsa. Pendidikan berperan penting dalam menyemai karakter para calon pemimpin bangsa. Tanpa kecuali satuan pendidikan SMA/MA di Provinsi Bali yang menjadi salah satu "produsen" pencetak generasi bangsa.

Berdasarkan data populasi dan sampel siswa SMA dan MA kelas XI di Provinsi Bali adalah sebagai berikut:

Tabel 1. Populasi dan sampel

\begin{tabular}{llllll}
\hline No & Satuan Pendidikan & Populasi & Sampel & & \\
\hline & & SMA/MA & Siswa & SMA/MA & Siswa \\
\hline 1 & SMA & 161 & 87.540 & 16 & 160 \\
\hline 2 & SMA & 25 & 3.827 & 1 & 10 \\
\hline Jumlah & 186 & 91.367 & 17 & 170 & \\
\hline
\end{tabular}

Karakter peserta didik SMA dan MA di Provinsi Bali dilihat dari 5 dimensi karakter (1) religiusitas, (2) nasionalisme, (3) kemandirian, (4) gotong royong, dan (5) integritas dilihat dari beberapa hal. 


\section{Deskripsi Responden}

Dekripsi responden dapat dilihat dari perbedaan (1) jurusan, (2) jenis kelamin, dan (3) agama.

Dilihat dari perbedaan jurusan tampak bahwa (1) jurusan IPA sebanyak 63,53 \%, (2) jurusan IPS sebanyak $30 \%$, dan (3) jurusan bahasa sebanyak $6,47 \%$. Hal ini tampak gambar sebagai berikut:

\section{Gambar 1}

Persentase responden berdasarkan jurusan

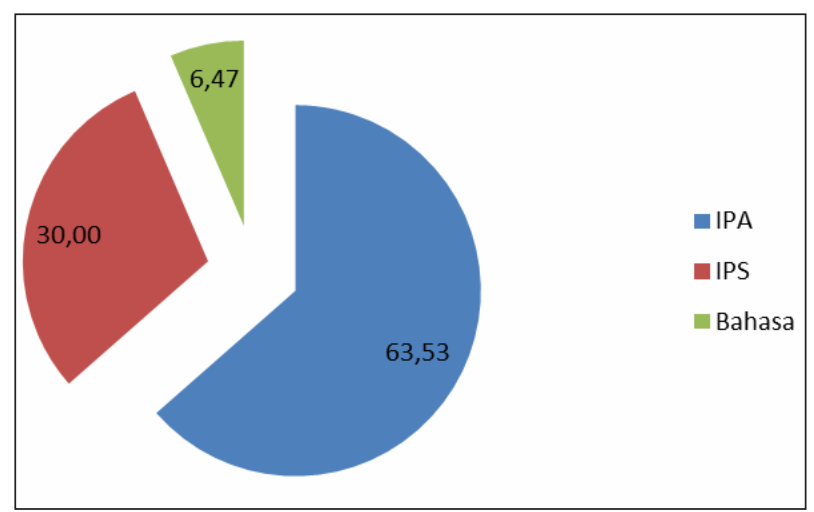

Dilihat dari perbedaan jenis kelamin bahwa (1) laki-laki sebanyak 51,76\%, (2) perempuan sebanyak 48,24\%. Hal ini tampak gambar sebagai berikut:

\section{Gambar 2}

Persentase responden berdasarkan jenis kelamin

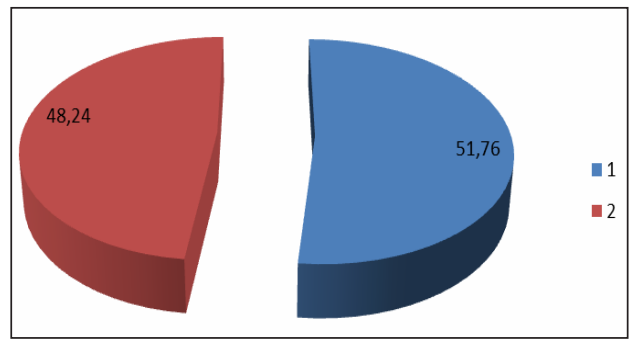

Dilihat dari perbedaan agama tampak bahwa (1) Siswa beragama Islam sebanyak $20 \%$, (2) Siswa beragama Hindu sebanyak 
$74,71 \%$, (3) Siswa beragama Budha sebanyak 4,12 \%, (4) Siswa beragama Kristen sebanyak 0,59 \%; dan (5) agama laiannya sebanyak 0,59 \%. Hal ini tampak gambar sebagai berikut:

\section{Gambar 3}

Persentase responden berdasarkan agama

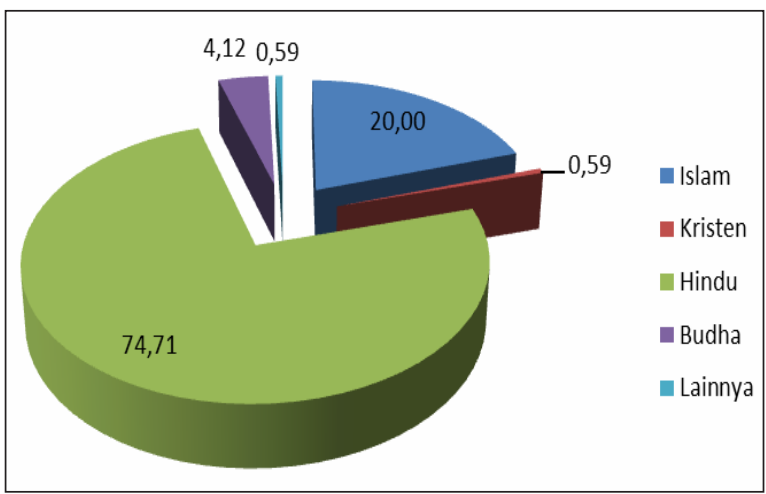

\section{Karakter Peserta Didik SMA dan MA}

Berdasarkan temuan penelitian ditemukan bahwa karakter peserta didik SMA dan MA di Provinsi Bali sebesar 3,37 \%, dengan masing-masing dimensi karakter sebagai berikut: (1) karaker religius sebesar 3,41\%; (2) karakter nasionalisme sebesar 3,51 \%; (3) karakter kemandirian sebesar 3,28 \%; (4) karakter gotong royong sebesar 3,30 \%; dan (5) karakter integritas sebesar 3,36\%.

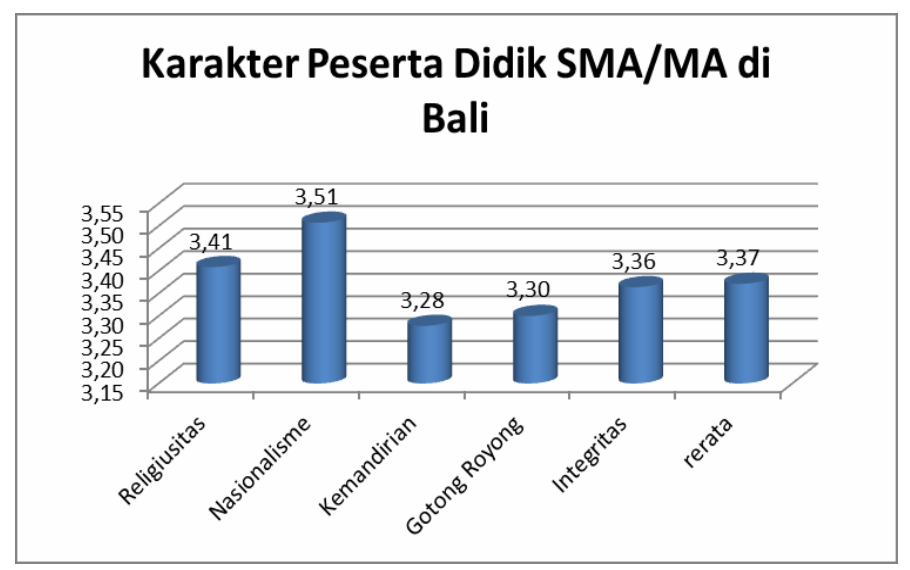


Berdasarkan temuan penelitian diketahui bahwa nilai kemandirian paling rendah dibandingkan dengan nilai karakter yang lain. Padahal dalam UU Nomor 20 Tahun 2003 pasal 3 menyebutkan bahwa salah satu tujuan pendidikan nasional adalah menjadikan anak didik menjadi mandiri. Nilai kemandirian rendah bisa jadi karena ini karena responden adalah anak-anak generasi milenial (usia SMA/MA). Meskipun secara fisik mereka sudah sempurna tetapi dari sisi ekonomi masih sangat ketergantungan dengan orang tua mereka.

Rendahnya nilai gotong royong siswa bisa jadi disebabkan memudarnya nilai-nilai gotong royong di masyarakat. Hal ini bisa dilihat di masyarakat secara umum bahwa saat ini nilai gotong royong misalnya kerja bhakti di lingkungan masyarakat bergeser menjadi bentuk lain yakni bentuk iuran. Demikian juga sistem keamanan di perumahan yakni sistem ronda diganti dengan sistem keamanan satpam/security.

\section{Penutup}

Karakter peserta didik SMA/MA dilihat dari lima dimensi karakter yaitu religiusitas, nasionalisme, kemandirian, gotong royong, dan integritas. Temuan penelitian menunjukkan bahwa indeks karakter peserta didik SMA dan MA di Provinsi Bali sebesar 3,37 (sangat baik). Dilihat dari lima dimensi tergambar sebagai berikut: karakter religius sebesar 3,41; karakter nasionalisme sebesar 3,51; karakter kemandirian sebesar 3,28; karakter gotong royong sebesar 3,30; karakter integritas sebesar 3,36. Berdasarkan hal tersebut karakter nasionalisme dan religiusitas memperoleh nilai tinggi dan karakter kemandirian dan gotong royong memperoleh nilai rendah.

Memudarnya nilai kemandirian bangsa dan semangat gotong royong perlu mendapat perhatian serius. Berdasarkan uraian di atas maka rekomendasi penelitian ini adalah sebagai berikut: 
1. Kementerian Pendidikan dan Kebudayaan RI dan Kementerian Agama RI perlu meningkatkan strategi penguatan pendidikan karakter peserta didik SMA dan MA, terutama penguatan pendidikan karakter kemandirian dan gotong royong

2. Kementerian Pendidikan dan Kebudayaan RI dan Kementerian Agama RI perlu menyusun pedoman pelaksanaan dan pengembangan kompetensi pengawas dan guru berupa pelatihan pengembangan silabus dan RPP dalam rangka penguatan pendidikan karakter melalui pembelajaran di kelas

3. Pihak sekolah dan madrasah perlu mengembangkan budaya sekolah/madrasah sesuai dengan kondisi lingkungan setempat.

4. Pembina ekstrakurikuler perlu mengembangkan kegiatan ekstrakurikuler berbasis karakter atau melakukan revitalisasi ektrakurikuler yang ada ke arah penguatan karakter.

\section{Ucapan Terima Kasih}

Penelitian ini merupakan bagian penelitian survei nasional. Oleh karena itu, peneliti mengucapkan terima kasih kepada seluruh tim peneliti, khususnya tim peneliti dari Balai Penelitian dan Pengembangan Agama Semarang: Umi Muzayanah, Mulyani Mudis Taruna, AM Wibowo, Mukhtaruddin, Ahmad Muntakhib, Nugroho Eko Atmanto, dan Siti Muawanah. Rasa terima terima khusus, terutama kepada para surveyor di Bali: Hendra Jaya, Saiful

Lizan, Syariful Anam, Ilham Hadi, Ketut Suarning, Made Martini dan Putu Rena. Selain itu, kegiatan ini tidak akan terlaksana tanpa bantuan anggaran dari Puslitbang Pendidikan Agama dan Keagamaan, Badan Litbang dan Diklat Kementerian Agama RI tahun anggaran 2019. 


\section{DAFTAR PUSTAKA}

Koesoema A, Doni. 2018. Pendidikan Karakter Berbasis Kultur Sekolah; Menumbuhkan Ekosistem Moral Pendidikan. DIY: Penerbit Kanisius

Komalasari, Kokom dan Didin Saripudin. 2017. Pendidikan Karakter; Konsep dan Aplikasi Living Values Education. Bandung: Refika Aditama

Lickona, Thomas. 1992. Educating for Character: How Our School Can Teach Respect and Responsibility. New York, Toronto London, Sydney, Aucland: Bantam Books

Lubis, Mawardi. 2014. Evaluasi Pendidikan Nilai; Perkembangan Moral Keagamaan Mahasiswa PTAIN, cetakan ke-4. Yogyakarta: Pustaka Pelajar

Nata, Abuddin. 2018. Psikologi Pendidikan Islam. Depok: RajaGrafindo Persada

Prabtama, Rizki. 2019. "Muhammadiyah Mendidik Karakter" dalam Majalah Suara Muhammadiyah; Syiar Islam Berkemajuan, Edisi 12, 16-30 Juni 2019

Sofanudin, Aji. 2015. Internalisasi Nilai-nilai Karakter Bangsa melalui Mata Pelajaran Pendidikan Agama Islam pada SMA Eks-RSBI Kabupaten Tegal, Jurnal SMART, Volume 01 Nomor 02 Desember 2015

--------------. 2017. Aktivitas Keagamaan Siswa dan Jaringan Mentoring Rohis SMA Negeri di Kabupaten Sukoharjo, Jurnal SMART, Volume 03 Nomor 01 Juni 2017

(https://blasemarang.kemenag.go.id/journal/index.php/smart/ article/view/248).

Sugiyono, 2014. Metode Penelitian Manajemen; Pendekatan Kuantitatif, Kualitatif, Kombinasi, Penelitian Tindakan, Penelitian Evaluasi. Bandung: Alfabeta

Tim Peneliti Puslitbang Pendidikan Agama dan Keagamaan, Badan Litbang dan Diklat Kementerian Agama RI. 2018. Survei Integritas Peserta Didik SMA dan MA. Jakarta: Puslitbang Pendidikan Agama dan Keagamaan 
Undang-undang Nomor 20 Tahun 2003 tentang Sistem Pendidikan Nasional

Wibowo, Agus. 2013. Manajemen Pendidikan Karakter di Sekolah; Konsep dan Praktik Implementasi. Yogyakarta: Pustaka Pelajar

https://www.kemdikbud.go.id/main/blog/2019/12/tahun2021 ujian-nasional-diganti-asesmen-kompetensi-dansurvei-karakter 


\section{BIODATA PENULIS}

Aji Sofanudin. Lahir di Tegal, 17 Desember 1978. Saat ini sebagai Peneliti Ahli Madya pada Balai Penelitian dan Pengembangan Agama Semarang. Ia adalah alumni S1 Fakultas Tarbiyah IAIN Walisongo tahun 2002 jurusan PAI, S2 UII Yogyakarta konsentrasi Islamic Research lulus Tahun 2009, dan S3 Program Doktor Manajemen Pendidikan Universitas Negeri Semarang lulus Tahun 2016. Karya yang pernah diterbitkan diantaranya adalah (1) Aktivitas Keagamaan Siswa dan Jaringan Mentoring Rohis SMA Negeri di Kabupaten Sukoharjo, terbit Jurnal Smart, Volume 3 Nomor 1 tahun 2017, (2) Research Innovation Model at The Office of Religious Research and Development Semarang, terbit Jurnal Bina Praja Volume 10 No 1 tahun 2018, (3) Integrasi Pendidikan Formal dan Non Formal; Respon Satuan Pendidikan terhadap Kebijakan FDS, Bagian buku dari "Kapita Selekta KF Doktor; Melintasi Tapal Batas Keilmuan" terbit tahun 2018, (4) Keberagamaan Siswa SMA Negeri Sukoharjo, bagian dari buku Transmisi Keberagamaan Rohis; Eksistensi, Ekspresi dan Politik, terbit tahun 2018, (5) Curriculum Typology of Islamic Religion Education in Integratedi Islamic School (SIT), Jurnal EDUKASI Puslitbang Pendidikan Agama dan Keagamaan Badan Litbang dan Diklat Kemenag RI, Volume 17, Nomor 1 Januari Juni 2019, (6) Kebijakan Kementerian Agama dalam Pelayanan Pendidikan Agama Kelompok Minoritas, Jurnal PENAMAS Balai Litbang Agama Jakarta, Volume 32, Nomor 1, Januari Juni 2019, (7) Survey Akhlak Siswa SMA Negeri di 
Provinsi Jawa Tengah, Jurnal AL-QALAM, Balai Litbang Agama Makassar, Volume 25, Nomor 1 Januari Juni 2019, (8) Best Practice Implementasi Kurikulum pada Sekolah Alam Insan Mulia (SAIM) Surabaya, Jurnal SMART Balai Litbang Agama Semarang, Volume V, Nomor 1, Januari Juni 2019, (9) Perbedaan Nilai Kerja Guru Laki-laki dan Perempuan pada Madrasah Berbasis Pesantren di Kabupaten Ponorogo Jawa Timur, Jurnal AL-QALAM, Balai Litbang Agama Makassar, Volume 26, Nomor 1 Januari Juni 2020. No HP 08174151699 email: ajisofan@gmail.com.

Mustolehudin. Lahir di Kebumen, 25 Mei 1974. Saat ini sebagai Peneliti Ahli Madya pada Balai Penelitian dan Pengembangan Agama Semarang. Pendidikan S1 ditempuh di IAIN Walisongo Fakultas Ushuluddin Jurusan Akidah Filsafat lulus tahun 1998. Sambil menyelesaikan studi ia pernah bekerja di Bank Pembangunan Daerah Capem IAIN Walisongo Semarang sebagai office boy kurang lebih 7 tahun. Mulai bekerja di Balai Litbang Agama Semarang pada tahun 2003 dan mendapat kesempatan tugas belajar S1 Ganda Ilmu Perpustakaan di Universitas Yarsi Jakarta dari Badan Litbang dan Diklat Kemenag RI dan lulus tahun 2007. Tahun 2010 berkesempatan meneruskan studi pada Pascasarjana IAIN Walisongo dengan kosentrasi Etika/Tasawuf dan lulus tahun 2012. Beberapa tulisannya yang pernah dimuat dalam berbagai jurnal adalah Etika Jawa dalam Perspektif Islam :Kajian terhadap Serat Wirid Hidayat Jati"(Jurnal Analisa No.18. Tahun IX Oktober 2004, Semarang), Dimesi Moral dalam Kidung Mantra Wedha:Kajian Filosofis terhadap Mistik dan Makrifat Sunan Kalijaga” (Jurnal Analisa No.19 Tahun X April 2005), Fungsi Teknologi Informasi (Internet) dalam Penyebaran Informasi Keagamaan"(Jurnal Analisa, Vol XII, No.01 JanuariApril 2007), Pengelolaan Literatur Masjid Pada Era Globalisasi Informasi (Jurnal Analisa, Vol, XVI, No.02 Juli-Desember 2009), Elektronik 